\section{Synthesis and Crystal Structure of $\left(\mathrm{Sb}_{1 / 3} \mathrm{Zn}_{2 / 3}\right) \mathrm{GaO}_{3}(\mathrm{ZnO})_{3}$}

\section{Jennifer Garling, ${ }^{*[a]}$ Wilfried Assenmacher, ${ }^{[a]}$ and Werner Mader ${ }^{[a]}$}

Keywords: Zink oxides; Antimony; Crystal structure

A high temperature $\left(1350{ }^{\circ} \mathrm{C}\right)$ route in sealed platinum tubes was used for the synthesis of pure powders of $\left(\mathrm{Sb}_{1 / 3} \mathrm{Zn}_{2 / 3}\right) \mathrm{GaO}_{3}(\mathrm{ZnO})_{3}$. Single crystals of the compound were grown from a $\mathrm{K}_{2} \mathrm{MoO}_{4}$ flux.

$\left(\mathrm{Sb}_{1 / 3} \mathrm{Zn}_{2 / 3}\right) \mathrm{GaO}_{3}(\mathrm{ZnO})_{3}$ consists of an alternate stacking of $\left[\left(\mathrm{Sb}_{1 / 3} \mathrm{Zn}_{2 / 3}\right) \mathrm{O}_{2}\right]^{-}$and $\left[\left(\mathrm{GaZn}_{3}\right) \mathrm{O}_{4}\right]^{+}$units corresponding to $\mathrm{CdI}_{2}$ and wurtzite structure type motifs, respectively. Inversions of the $\mathrm{ZnO}_{4}$-tetrahedra occur (i) at the octahedral layers and (ii) halfway in the wurtzite type regions where trigonal bipyramidal coordinated cations build the boundary. The crystal structure has been determined by electron diffraction, HR-TEM and single-crystal X-ray diffraction. $\left(\mathrm{Sb}_{1 / 3} \mathrm{Zn}_{2 / 3}\right) \mathrm{GaO}_{3}(\mathrm{ZnO})_{3}$ crystallises trigonal $\left(P 3_{1} 12 ;\right.$ No. 151 ; $a=5.60 \AA, c=42.02 \AA)$. The compound described here has the structural characteristics as other known members of the general formula $\mathrm{ABO}_{3}(\mathrm{ZnO})_{m}$ with $m=$ integer, but an ordering of the cations within the $\left[\left(\mathrm{Sb}_{1 / 3} \mathrm{Zn}_{2 / 3}\right) \mathrm{O}_{2}\right]$ - octahedral layer leading to a superstructure. ${ }^{[1]}$

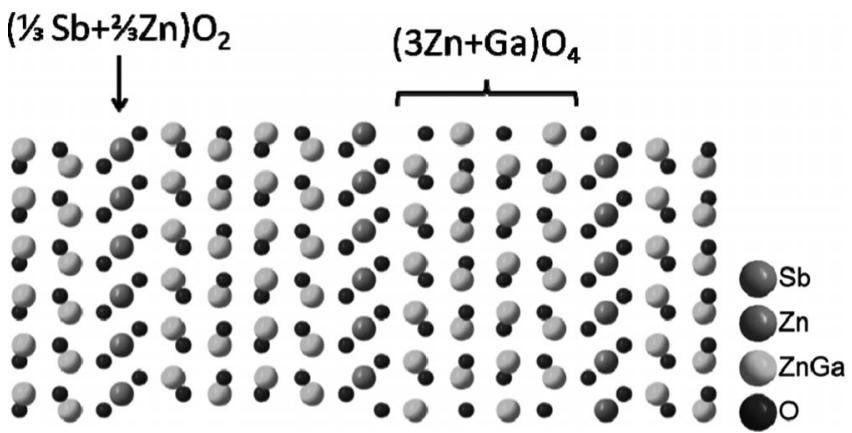

Figure 1. Crystal Structure of $\left(\mathrm{Sb}_{1 / 3} \mathrm{Zn}_{1 / 3}\right) \mathrm{GaO}_{3}(\mathrm{ZnO})_{3}$.

[1] I. Keller, W. Mader, Z. Anorg. Allg. Chem. 2010, 636, 1045-1049.

\section{Synthesis and Crystal Structure of $\mathrm{ZnSbO}_{2} \mathrm{I}$}

\author{
Nadia Rück, ${ }^{[a]}$ and Arno Pfitzner*[a]
}

Keywords: Hydrothermal Synthesis, Zinc, Antimony, Iodine, Crystal Structure

Colorless single crystals of $\mathrm{ZnSbO}_{2} \mathrm{I}$ were obtained by reaction of $\mathrm{ZnO}, \mathrm{Sb}_{2} \mathrm{O}_{3}$ and $\mathrm{ZnI}_{2}$ in a stoichiometric ratio of 1:1:1. Water was added and the mixture was tempered in Teflon-lined autoclaves at $120^{\circ} \mathrm{C}$ for 13 days. The structure was solved by single-crystal X-ray diffraction. The compound crystallizes in the monoclinic space group $P 2(1) / m$, with $a=5.25(5) \AA, b=$ 8.47(9) $\AA, c=7.47(2) \AA, \beta=94.4(3)^{\circ}, V=331.94 \AA^{3}$ and $Z$ $=4$. The crystal structure refinement based on 813 reflections converged at $R 1=3.76 \%$ and $w R 2=0.0964$, respectively. The structure consists of puckered layers of distorted $\left[\mathrm{ZnO}_{3} \mathrm{I}\right]$ tetrahedra and strings of $\mathrm{Sb}^{3+}$ cations coordinated by four oxygen atoms as described by Warzycha for $\mathrm{ZnSb}_{2} \mathrm{O}_{3} \mathrm{X}(\mathrm{OH}){ }^{[1]}$

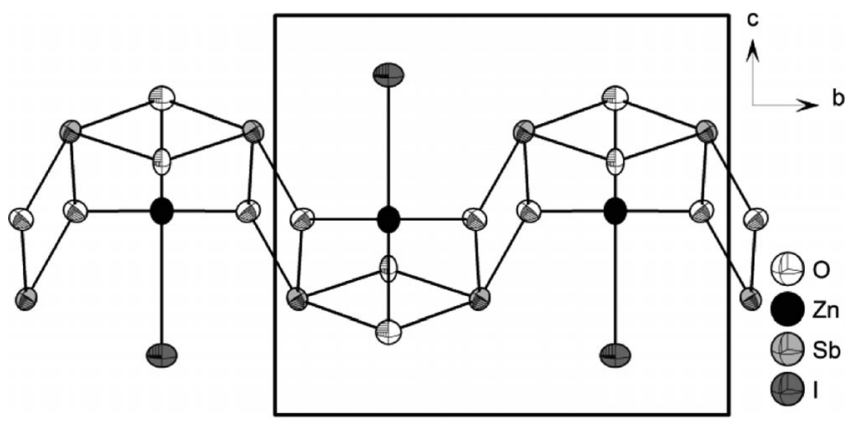

Figure 1: Structure of $\mathrm{ZnSbO}_{2} \mathrm{I}$ viewed along [100]

[1] K. Warzycha, Dissertation, University of Regensburg, 2010.

\footnotetext{
* Dipl.-Chem. J. Garling E-Mail: jgarling@uni-bonn.de

[a] Institut für Anorganische Chemie, Universität Bonn, Römerstr. 164, 53117 Bonn, Germany
}

\footnotetext{
* Prof. Dr. A. Pfitzner

E-Mail: arno.pfitzner@chemie.uni-regensburg.de

[a] Institut für Anorganische Chemie, Universität Regensburg, Universitätsstr. 31, 93053 Regensburg, Germany
} 